\title{
EFISIENSI PEMASARAN TELUR AYAM RAS DI KOTA MANADO
}

\author{
Darwin Tobaol, M. Rundengan", E.K.M. Endoh, S. P. Pangemanan
}

Fakultas Peternakan Universitas Sam Ratulangi Manado, 95115

\begin{abstract}
ABSTRAK
Penelitian bertujuan untuk mengetahui pola, margin, dan efisiensi pemasaran telur ayam ras di kota Manado. Hasil penelitian menunjukkan jumlah telur pada saluran pemasaran dari produsen ke konsumen melewati pedagang pengeser sebesar 1.114 baki dan 33.420 butir sedangkan saluran pemasaran dari produsen ke konsumen melalui pedagang pengumpul dan pedagang pengecer sebesar 956 baki dan 28.680 butir telur. Penelitian menunjukkan bahwa margin pemasaran pada saluran pemasaran pertama sebesar Rp. 9.636. Margin pemasaran pada saluran pemasaran dua sebesar Rp. 6.090. Efisiensi pemasaran pada saluran pertama sebesar $87,33 \%$ dan efisiensi pemasaran pada saluran dua sebesar 59,19\%.

Kata kunci: Saluran pemasaran, margin pemasaran, efisiensi pemasaran.
\end{abstract}

\section{ABSTRACT}

MARKETING EFFCIENCY OF CHICKEN EGGS IN MANADO CITY. Research proposed to seek the pattern, margin and marketing efficiency of egg layer in Manado City. The research resulted that

Korespondensi (corresponding author) Email: meiskerundengan@yahoo.com earning eggs amounted 1114 trays and 33420 item at first marketing channel. It earn 956 trays and 28680 item at second marketing channel. The research illustrated the first channel marketing margin amount IDR 9636. Then, second marketing margin amount IDR 6090. The first marketing channel efficient amount $87,33 \%$ and $59,19 \%$ in second channel.

Key word: Marketing channel, margin , efficiency.

\section{PENDAHULUAN}

\section{Latar Belakang}

Seiring dengan semakin meningkatnya laju pertumbuhan penduduk di daerah propinsi Sulut dan semakin membaiknya tingkat pendapatan yang ditunjang pula dengan meningkatnya taraf pendidikan, maka tingkat konsumsi masyarakat terhadap produk-produk peternakan mengalami peningkatan. Daging, telur dan susu merupakan sumber protein yang sangat dibutuhkan masyarakat. Telur ayam ras merupakan salah satu produk pangan hasil ternak yang mempunyai peran sangat penting dan strategis 
dalam masyarakat karena harganya relatif murah dan mempunyai kandungan gizi tinggi, terutama protein serta nilai cerna oleh tubuh yang tinggi pula.

Kota Manado sebagai ibukota Propinsi Sulawesi Utara menjadi pasar terbesar produk daging dan telur hal ini disebabkan karena pembangunan kota Manado dengan program kota tujuan wisata sangat terlihat jelas dengan bertumbuhnya usaha-usaha pengelolaan makanan, seperti rumah makan, industry pengolahan makanan selain dengan bertambahanya jumlah masyarakat dan semakin meningkatnya tingkat pendidikan dan juga pendapatan masyarakat. Menurut BPS Sulut (2017), bahwa produksi telur ayam ras Propinsi Sulut dalam 5 tahun terakhir mengalami peningkatan yaitu pada tahun 2012 sebanyak 8.551.583 menjadi 10.597 .825 butir pada tahun 2017. Ketersediaan produk ini sangat dipengaruhi oleh lembaga-lembaga pemasaran hingga sampai ke tangan konsumen akhir dengan harga yang sesuai/terjangkau oleh masyarakat.

\section{Aktifitas}

pemasaran

merupakan salah satu kegiatan yang paling penting, dimana pada kegiatan itu tujuannya adalah menyalurkan produk dari produsen sampai ketangan konsumen akhir, yang melibatkan beberapa lembaga pemasaran untuk memudahkan produsen dalam menyalurkan produk.Pemasaran dapat dinyatakan efisiensi apabila memenuhi dua syarat yaitu mampu menyampaikan hasil-hasil dari peternak ke konsumen dengan biaya yang murah dan mampu mengadakan pembagian yang adil dari keseluruhan harga yang dibayar konsumen akhir kepada semua pihak yang terlibat dalam kegiatan produksi dan juru tataniaga tersebut. Efisiensi pemasaran dipengaruhi oleh beberapa faktor diantaranya adalah hal-hal yang mendukung terjadinya pemasaran yang efisien yaitu struktur pasar dan lembaga pemasaran yang ikut adil dalam proses pemasaran.

CV. Gunawan Dharma adalah usaha peternakan ayam petelur yang terletak di kota Manado yang telah lama mensuplai kebutuhan telur ke kota Manado dan sekitarnya. Penelitian difokuskan pada aspek pemasaran peternakan CV. Gunawan Dharma dalam kota Manado yaitu 
dalam rangka menyampaikan produk telur ayam ras dari produsen hingga sampai ke konsumen akhir.

Tujuan penelitian, yakni untuk mengetahui pola saluran, margin dan efisiensi pemasaran telur ayam ras di kota Manado.

\section{METODE PENELITIAN}

Penelitian ini dilaksanakan Kota Manadopada CV Gunawan Dharma dari tanggal 1 April sampai 29 Mei 2018.

\section{Penetuan Sampel}

Penentuan sampel produsen mengunakan metode studi kasus (case study) yaitu penelitian tentang status subjek penelitian yang berkenaan dengan suatu fase spesifik atau khas dari keseluruhan personalitas (Nazir 1988). Pemilihan usaha peternakan ayam ras petelur CV. Gunawan Dharma dijadikan studi kasus karena usaha ini memiliki keunggulan yaitu satu-satunya usaha peternakan ayam ras petelur yang ada di kota Manado mempunyai pengalaman beternak cukup lama, memiliki catatan penjualan yang baik.

Saluran pemasaran ditentukan melalui pendekatan langsung mengikuti aliran produksi telur dari produsen sampai ke konsumen akhir. Responden lembaga pemasaran ditentukan dengan metode Snow ball sampling yaitu teknik menentukan responden secara berantai dengan meminta informasi pada orang yang telah diwawancarai dan seterusnya (Nazir, 1988).

\section{Metode Pengumpulan Data}

Data yang diambil dalam penelitian ini yaitu data primer dan data skunder. Data primer diperoleh dari pengamatan langsung terhadap jual beli yang terjadi di tempat produsen telur, dipasar tradisional dan ditempat lainya di Kota Manado dan melalui wawancara. Data sekunder diperoleh dari instansi terkait dengan penelitian ini yaitu Kantor Statistik dan Kantor Dinas Pasar.

Upaya menjelaskan keadaan umum responden baik produsen maupun konsumen sebagai lembaga pemasaran serta saluran pemasaran menggunakan analisis deskriptif dengan penjelasan melalui narasi ilmiah, bagan/gambar, table, rataan dan persentase dengan bantuan program Microsoft Excell.Untuk menghitung margin pemasaran dan 
share margin pada masingmasingtataniaga pemasaran I dan II, mengikuti rumus sebagai berikut (Hastuti danRahim, 2007).

a. Margin pemasaran dihitung dengan rumus:

$$
\text { MP } \quad \text { = Pr-Pf }
$$

Keterangan :

MP : $\quad$ Margin pemasaran

Pr : Harga konsumen

akhir

Pf : Harga dari produsen

b. Share margin, dengan rumus (Hastuti dan Rahim, 2007)

$$
S p=\frac{P f}{P r} \times 100 \%
$$

Keterangan :

Sp : Bagian harga yang diterima produsen

Pf : Harga ditingkat produsen

Pr : Harga ditingkat

konsumen

Kriteria Keputusan :

Jika Share > $60 \%$, bagian harga pemasaran telur ayam ras adil.

Jika Share < $60 \%$, bagian harga pemasaran telur ayam ras tidak adil. c.. Untuk menghitung efisiensi pemasaran telur ayam dengan rumus (Nuraeni, 2009):

Efisiensi Pemasaran $(\mathbf{E P})=($ Biaya Pemasaran/Nilai produk yang dijual) x $100 \%$

Kriteria:

Jika e $>1 \%$ efisien

Jika e $<1 \%$ tidak efisien

\section{HASIL DAN PEMBAHASAN}

Tabel 1 menunjukkan bahwa usaha peternakan $\mathrm{CV}$ Gunawan Dharma didirikan pada tahun 1977 dan masih tetap berlangsung sampai sekarang. Status usaha peternakan adalah milik sendiri. Pemilik usaha peternakan tersebut berusia 84tahun, usia peternak digolongkan dalam kelompok usia tidak produktif. Usia ini tidak sesuai dengan pendapat Kusumodiwidho (1983), yang termasuk kelompok produktif adalah yang berumur 15-64 tahun. Hal ini disebabkan karena anak-anak pemilik usaha telah memiliki usaha lain dan tidak bisa menangani usaha ayam petelur. 
Tabel 1 Karakteristik Usaha Peternakan CV. Gunawan Dharma

\begin{tabular}{cll}
\hline No & \multicolumn{1}{c}{ Uraian } & \multicolumn{1}{c}{ Keterangan } \\
\hline 1. & Tahun didirikan & 1977 \\
2. & Status Peternakan & Milik sendiri \\
3. & Umur Peternak & 84 Tahun \\
4. & Pendidikan Akhir & SMA \\
5. Pengalaman berternak & 41 Tahun \\
6. Pemilik ternak : & \\
& - Ayam Ras Petelur Fase Layer & 13.000 ekor \\
& - Ayam Ras Petelur Fase Stater & $9.000 \quad$ ekor \\
& - Ayam Ras Petelur Fase Grower & $6.000 \quad$ ekor \\
7. Tenaga Kerja & 6 orang \\
\hline
\end{tabular}

Tabel 1 memperlihatkan bahwa peternak mempunyai tingkat pendidikan menengah yaitu Sekolah Menengah Atas. Hasil penelitian menunjukan bahwa, lapeternak telah cukup berpengalaman dan mempunyai keahlian dalam pengolahan usaha peternakan ayam ras petelur, peternak telah berpengalaman 41 tahun. Dengan makin lamanya pengalaman peternak dalam usaha ayam ras petelur lebih mudah mengambil keputusan yang berhubungan dengan proses produk usahanya dalam rangka peningkatan produk usaha peternakannya.

Tenaga kerja yang digunakan untuk menangani ayam ras petelur fase layer sebanyak 13.000 ekor adalah 6 orang. Rasyaf (1991) menyatakan bahwa 1 orang tenaga kerja laki-laki dewasa mampu mengolah 3500 ekor ayam ras petelur fase layer secara manual. Jumlah tenaga kerja yang menangani kandang CV. Gunawan Dharma sebanyak 6 orang dengan rata-rata pemeliharaan ternak per unit yaitu 2166 ekor berarti terjadi kelebihan tenaga kerja dibandingkan dengan seperti dianjurkan Rasyaf (2001).

Karakteristik pedagang besar telur di kota Manado dalam Tabel 2 berikut ini. 
Tabel. 2. Jumlah, Rataan Umur, Pendidikan dan lama usaha Pedagang Besar

\begin{tabular}{|c|c|c|}
\hline No. & Uraian & Keterangan \\
\hline 1 & Jumlah Pedagang & 11 \\
\hline 2 & Rata- rata Umur & 43,64 Tahun \\
\hline \multirow[t]{6}{*}{3} & Pendidikan & \\
\hline & a. $\mathrm{SD}$ & - \\
\hline & b. SMP & 3 Orang \\
\hline & c. SMA & 3 Orang \\
\hline & d. PT (Perguruan Tinggi) & 5 Orang \\
\hline & e. Tidak Sekolah & - \\
\hline 4 & Lama Usaha & 10,18 Tahun \\
\hline
\end{tabular}

Tabel 2 diatas, menjelaskan bahwa pedagang besardengan memiliki ratarata umur 43 tahun yang menurut BPS (2017) masuk dalam usia produktif dengan tingkat pendidikan sebagian besar pada tingkat perguruan tinggi,hal ini menggambarkan bahwa pekerjaan pedagang besar adalah seorang usahawan yang memerlukan pengetahuan formal terlebih dalam memperkirakan biaya dan keuntungan usaha pada saluran pemasaran seperti biaya transport, pergudangan, pengepakan dan lainnya. Hal lainnya yaitu dengan lama usaha atau memiliki pengalaman berusaha selama 10 tahun.
Tabel 3 menjelaskan bahwa pedagang besar dengan memiliki rata-rata umur 38 tahun yang menurut BPS (2017) masuk dalam usia produktif dengan tingkat pendidikan sebagian besar pada tingkat perguruan tinggi, hal ini menggambarkan bahwa pekerjaan pedagang besar adalah seorang usahawan yang memerlukan pengetahuan formal terlebih dalam memperkirakan biaya dan keuntungan usaha pada saluran pemasaran seperti biaya transport, pergudangan, pengepakan dan lainnya. Hal lainnya yaitu dengan lama usaha atau memiliki pengalaman berusaha selama 10 tahun. 
Tabel. 3. Jumlah, Rataan Umur, Pendidikan dan lama usaha Pedagang Pengumpul

\begin{tabular}{rlc}
\hline No. & Uraian & Keterangan \\
\hline 1 & Jumlah Pedagang & 11 \\
2 & Rata- rata Umur & 38 Tahun \\
3 & Pendidikan & \\
& a. SD & 2 Orang \\
& b. SMP & 5 Orang \\
& c. SMA & 4 Orang \\
& d. PT (Perguruan Tinggi) & - \\
& e. Tidak Sekolah & - \\
4 & Lama Usaha & $1.1 / 2-6$ Tahun
\end{tabular}

Tabel. 4. Jumlah, Rataan Umur, Pendidikan dan lama usaha Pedagang Pengecer

\begin{tabular}{rlcc}
\hline No. & Uraian & Keterangan & $\%$ \\
\hline 1 & Jumlah Pedagang & 11 & 100 \\
2 & Rata- rata Umur & 46 Tahun & \\
3 & Pendidikan & & \\
& a. SD & 2 Orang & \\
& b. SMP & 2 Orang & \\
& c. SMA & 7 Orang & \\
& d. PT (Perguruan Tinggi) & - & \\
& e. Tidak Sekolah & Lama Usaha & $2-12$ Tahun \\
\hline
\end{tabular}

Tabel 4 menunjukkan bahwa pedagang besar dengan memiliki rata-rata umur 43 tahun yang menurut BPS (2017) masuk dalam usia produktif dengan tingkat pendidikan sebagian besar pada tingkat perguruan tinggi, hal ini menggambarkan bahwa pekerjaan pedagang besar adalah seorang usahawan yang memerlukan pengetahuan formal terlebih dalam memperkirakan biaya dan keuntungan usaha pada saluran pemasaran seperti biaya transport, pergudangan, pengepakan dan lainnya. Hal lainnya yaitu dengan 


lama usaha atau memiliki
pengalaman berusaha selama 10
tahun.

\section{Pemasaran Telur Ayam Ras}

Menurut Rasyaf (1991),
pemasaran merupakan aktivitas
untuk menyampaikan produk
peternakan kekonsumen akhir. Oleh
karena ada banyaknya masalah
seperti lingkungan, situasi, dan
kondisi maka hal aktivitas tersebut
menjadi tidak mudah dilakukan.
Misalnya sarana dan prasarana,
membuat lembaga- lembaga
pemasaran yang ada di jalur
pemasaran dapat membantu dan
sangat berperan dalam proses
penyampaian produk ke konsumen
akhir.

Saluran pemasaran yang digunakan peternakan Gunawan Dharma dalam memasarkan telur ayam ras di kota Manado didapat dua saluran yaitu :

1. Peternak $\rightarrow$ Pedagang Pengecer $\rightarrow$ Konsumen.
2. Peternak $\rightarrow$ Pedagang Pengumpul $\rightarrow$ Pedagang Pengecer $\rightarrow$ Konsumen

Saluran pemasaran langsung ke konsumen, khususnya produk telur baik yang utuh maupun yang retak terjadi karena ada konsumen yang langsung membeli ketempat usaha dan ada konsumen yang sudah menjadi langanan tetap, yaitu konsumen pembuat kue yang ada di Manado, sedangkan untuk telur yang retak di jual kepada pembuatan kue dengan harga yang lebih rendah dari telur ayam yang utuh.

Saluran pemasaran dari peternak ke pedagang pengumpul/ pengecer ke konsumen terjadi juga karena pedagang yang sudah lama menjadi pelanggang, baik didaerah Manado maupun diluar daerah Manado antara lain, Bitung, Tomohon, Kotamobagu dan bahkan ada yang dari luar daerah Propinsi Sulawesi yaitu Kota Ternate (Gambar 1). 


\section{Saluran Pemasaran I}

$$
\text { Rp. } 38.000
$$

Rp. 45.681

Peternak Ayam Ras Petelur
Gunawan Dharma
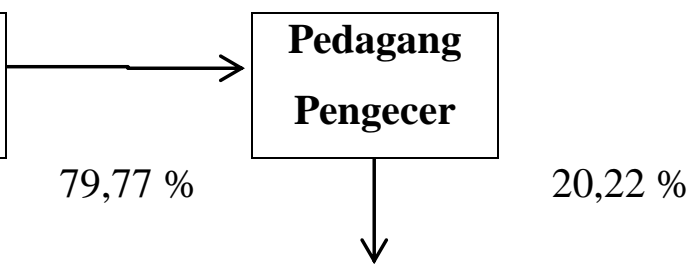

Konsumen

Akhir

Gambar 1. Saluran pemasaran I

\section{Saluran Pemasaran II}

$$
\text { Rp. } 38.000
$$

Rp. 44.090

\begin{tabular}{|c|c|}
\hline $\begin{array}{c}\text { Peternak Ayam Ras Petelur } \\
\text { Gunawan Dharma }\end{array}$ & \\
& \\
\hline
\end{tabular}

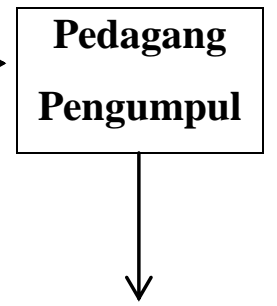

$93,99 \%$

Rp. 46.909



Gambar 2. Saluran pemasaran II

Produsen menjual telur kepada kepada konsumen akhir dengan pedagang pengecer dengan harga $\mathrm{Rp}$. harga Rp. 45.681/ baki (seperti 38.000/ baki dengan kapasitas telur terlihat pada Gambar 1). Gambar 2 rata-rata perbulan 79,77 \%, menunjukkan Produsen $\rightarrow$ Pedagang kemudian dari harga tersebut dijual Pengumpul $\rightarrow$ Pedagang Pengecer kembali oleh pedagang pengecer $\rightarrow$ Konsumen Akhir. Produsen 
menjual telur kepada pedagang pengumpul dengan harga Rp. 38.000/baki dengan kapasitas telur rata-rata perbulan $86,18 \%$, kemudian dari harga tersebut dijual kembali oleh pedagang pengumpul kepada pedagang pengecer dengan harga Rp. 44.090/ baki dengan kapasitas rata-rata perbulan adalah 93,99 \%, dan pedagang pengecer menjual kembali kepada konsumen akhir dengan harga Rp. 46.909/baki. Margin pemasaran pada saluran II ini adalah Rp. 46.909/ baki (seperti terlihat pada Gambar 2).

Analisis Biaya Pemasaran,

Distribusi Margin. Share Harga, Share Biaya, Share Keuntungan,

\section{Ratio Keuntungan Lembaga}

\section{Pemasaran I}

Dari hasil penelitian menunjukan bahwa saluran pemasaran 1 yang menyalurkan telur ayamras mulai dari produsen $\rightarrow$ pedagang

pengecer $\rightarrow$ konsumen akhir memliki marginsebesar Rp. 7681/baki dengan ketuntuan harga jual telur ayam ras petelur dari peternak ke pedagang pengecer besar dengan harga $\mathrm{Rp}$. 38.000/baki, biaya yang digunakan peternak dalam memperduksi telur ayam ras sebesar Rp. 25.466.500/baki, dan keuntungan yang diterima oleh peternak sebesar Rp. 16.864.500/baki. Share harga sebesar Rp. 83,18\% yangartinya bahwa setiaptelur Rp. 38.000/baki harga yang diterima oleh konsumen akhir, produsen memperoleh penerimaan sebesar Rp.16.865.500/baki. Komponen biaya pemasaran, distribusi margin, share harga, share biaya, share keuntungan dan ratio keuntungan telah mengikuti perhitungan dalam hasil penelitian sebelumnya (Ardhiana, dkk., 2014; Firini dkk, 2006; Fitriani, dan Rosanti, 2012; Kurniahningrum, dkk. 2008; Putritamara dkk, 2013; Mukson dkk., 2005; Rahmat dan Iskandar, 2006; Sujiwo dkk. 2009; Wantasen, et al., 2014).

Share biaya yang dikeluarkanpedagang pengecer sebesar 0,11\%yang berarti bahwa setiap Rp. 38.000/baki, pedagang pengecer memberikan kontribusi biaya sebesar Rp. 59,83/baki. Share keuntungan yang diterima oleh pedagang pengecer $20,05 \%$, yang mengartikan bahwa setiap penjualan telur Rp. 45.681/baki pedagang 
pengecer memberikan kontribusi biaya sebesar Rp. 59,83.

Analisis Biaya Pemasaran, Distribusi Margin, Share Harga, Share Biaya, Share Keuntungan, Ratio Keuntungan Lembaga Pemasaran II

Dari hasil penelitian menujukan bahwa saluran pemasaran II yang menyalurkan telur ayam ras petelur mulai dari produsen $\rightarrow$ pedagang

pengumpul $\rightarrow$ pedagang

pengecer $\rightarrow$ konsumen akhir memiliki margin sebesar Rp. 8.909/baki dengan ketentuan harga jual telur ayam ras dari peternak ke pedagang pengumpul dengan besar harga $\mathrm{Rp}$. 38.000/baki, biaya yang digunakan peternak dalam memperduksi telur ayam ras sebesar Rp. 25.466.500/baki dan keuntungan yang diterima oleh peternak sebesar Rp.-2,478.500/baki. Share harga yang diterima sebesar 113,78\% yang artinya bahwa setiap harga telur Rp. 38.000/baki harga yang diterima oleh konsumen akhir, produsen memperoleh penerimaan sebesar Rp.22.990.000. Share biaya serta biaya yang dikeluarkan oleh pedagang pengumpul dan pedagang pengecer untuk membeli telur masing masing adalah $18,74 \%$ dan $0,10 \%$ yang mengartikan bahwa setiap Rp. 38.000 dan Rp. 44,090 margin pemasaran, pedagang pengumpul memberikan kontribusi biaya sebesar Rp. $22 \%$ dan pedagang pengecer memberikan kontribusi biaya sebesar Rp. 9,57\%. Share keuntungan yang diterima oleh pedagang pengumpul dan pedagang pengecer berturut-turut $68,35 \%$ dan 99,88 \% yang mengartikan bahwa setiap penjualan telur Rp. 47.000/baki dan Rp. 46.909/baki pedagang pengumpul memberikan kontribusi biaya sebesar Rp. 22/baki dan pedagang pengecer memberikan kontribusi biaya sebesar Rp. 9,57.

\section{Analisis Margin Pemasaran Dan} Efisiensi Pemasaran

Dari hasil penelitian menunjukanbahwa angka margin pemasaran pada saluran pemasaran pertama sebesar Rp. 9.636. Margin pemasaran pada saluran pemasaran kedua sebesar Rp. 6.090. Hasil penelitian menunjukkan bahwa ternyata angka margin pemasaran pada saluran pemasaran satu lebih besar daripada angka margin pada saluran pemasaran dua. Lampiran 7 
juga menghasilkan nilai efisiensi pemasaran pada saluran pertama sebesar 87,33 persen. Nilai efisiensi pemasaran pada saluran kedua sebesar 53,75 persen. Berdasarkan kriteria efisiensi bila efisiensi lebih dari satu persen, maka pemasaran telah dinyatakan efisien. Dengan demikian baik saluran satu maupun saluran dua telah melampui kriteria efisiensi ( Ardhiana, dkk., 2014; Candra dkk. 2013; Fitriani dkk 2012; Putritamara,.dkk; Mukson dkk., 2005; Sarlan, dkk., 2017); Sujiwo dkk. 2009; Wantasen, et al 2014).

\section{KESIMPULAN}

1. Terdapat dua pola saluran pemasaran telur ayam ras dalam CV Gunawan Dharma di kota Manado.

2. Margin pemasaran pada saluran pemasaran dari produsen ke konsumen melewati pedagang pengecer lebih besar daripada angka margin pemasaran pada saluran produsen ke konsumen melewatoi pedagang pengumpul dan pedagang pengecer.
3. Kedua saluran pemasaran di Kota Manado sudah efisien

\section{DAFTAR PUSTAKA}

Ardhiana, Y, M., B.A Nugroho dan B. Hartono. 2014. Efisiensi Pemasaran Telur Ayam Ras di Kecamatan Ringin Rejo Kabupaten Kediri. Jurnal Ilmu Peternakan Fakultas Peternakan Universitas Brawijiaya. Malang.

Biro Pusat Statistik Sulawesi Utara, 2017. Sulut Dalam Angka. Manado

Candra A, Ismudiono, D. S Nazar, 2013. Analisis Tataniaga Telur Ayam Ras (Layer) Sistem Kemitraan UD. Jatinom Indah Kabupaten Blitar. Jurnal Agroveteriner $3(2): 27-32$.

Firini, A dan A.N. Yanti, 2006. Analisis Permintaan Telur Ayam Ras di Kota Padang dan Faktor yang Mempengaruhinya. Fakultas Peternakan Universitas Andalas Padang. Jurnal Peternakan Indonesia, 11(2): 112-122 
Fitriani, H. Ismono dan N. Rosanti, 2012. Produksi dan Tata Niaga Telur Ayam Ras. Program Studi Agribisnis Jurusan Sosial Ekonomi dan Bisnis pada Politeknik Negeri Lampung. Jurnal Bandar Lampung.

Kusumodiwidho. 1983. Bunga

Rampai Demogarfi. LP3ES.

Gramedia. Jakarta.

Mukson, S.I. H. Santosa, Setyawan dan B. Suryanto. 2005. Analisis Efisiensi Pemasaran Telur Ayam Ras di Kabupaten Kendal Jawa Tengah. Seminar Nasional Teknologi Peternakan dan Veteriner. Jurnal Fakultas Peternakan Universitas Diponegoro Semarang.

Nazir, M., 1988. Metode Penelitian. Ghalia Indonesia. Jakarta.

Nuraeni, 2009. Efisiensi Pemasaran

Ayam Ras di desa

Kalembarembeng Kecamatan

Bontonompo Kabupaten

Gowa. STTP Gowa.

Putritamara, J.A., Z. Fanani, H.D

Utami. 2013. Efisiensi

Pemasaran Telur Ayam di

Kecamatan Kanigoro
Kabupaten Blitar. Fakultas

Peternakan Universitas

Brawijaya.

Rasyaf, 1991.Pengelolaan Produksi

Telur. Kanisius. Yogyakarta.

Sarlan, M. Ahmadi, Rizal. 2017.

Efisiensi Usaha Peternakan

Ayam Ras Petelur di

Kabupaten Lombok Timur.

Jurnal Ilmiah Rinjani 5 (2):

34-40

Sujiwo, J.T., S. Wahyuningsih, S.

Supardi. 2014 Efisiensi

Pemasaran Kopi di

Kecamatan Singorojo

Kabupaten Kendal. Jurnal

Ilmu-ilmu Pertanian 4 (1)

:102-108

Wantasen, E., F.H. Elly and N.M. Santa, 2014. The Analysis of Semi Intensive Native Chicken Farming in Rural Communities. Jurnal of the Indonesian Tropical Animal Agriculture. 39(2): 126-133 